\title{
Povijesna sadašnjost i krhkost prirode viđeni kroz boravak u prirodi i afektivne percepcije planina
}

\section{Abstract: Historical present and the fragility of nature: affective atmospheres experienced in mountains}

Life insecurity and precariousness caused by neoliberal capitalist activities as well as the consequences that are felt worldwide as global crises (environmental, economic, migrant, health crisis) have a great impact on people and their sense of living a viable life, a "life that is worth of living." These circumstances create new forms of life - a life without the promise of stability and without a sense of security. However, with the feeling of insecurity, the promotion of anti-stress activities grows, such as outdoor activities (hiking, walking in nature, running, visiting nature parks, etc.). In this text, inspired by affect theories (Berlant, Ahmed) we analyze different perceptions of nature landscapes (mountains, nature parks in Croatia). We ask: how "nature" is experienced in a social atmosphere marked by different crises and which possibilities emerge from different imaginaries about nature.

Keywords: historical present, perception of nature, social atmosphere, consumerism

\section{Uvod}

Odrastao čovjek nekad ne čuje ni Boga ni boga, jednostavno ne čuje. Život ga odvede u planinu, koja mu kaže isto što bi mu i Bog rekao. Zapravo, planina dopire do čovjeka zato što - ne govori. Planina ne šuti, planina ne govori, planina jednostavno jest. I samo bivajući dopire do čovjeka, 
rezonira s čovjekom. Tamo si, i osjećaš da je nešto u tebi u rezonanciji s rajem oko tebe, s rajem u kojem si, jesi. Ljepota stišava um... (Birtić 94)

Posljednjih godina u Hrvatskoj svjedočimo popularizaciji nečeg što se najčešće zove antistresne aktivnosti na otvorenom, a što uključuje niz rekreativnih sportskih aktivnosti poput planinarenja, trčanja planinskim stazama (tzv. trail trčanje), brdskog biciklizma, (turno)skijanja, i čitava se jedna velika supkultura, sa svojim vrijednostima, svjetonazorima i uzorima razvija oko outdoor aktivnosti, pa tako i oko odlazaka u planine ili općenito u prirodu, što će biti uži fokus ovog teksta. lako su u Hrvatskoj planinarenje i alpinizam odavno prisutne aktivnosti (1875. godine u Zagrebu je osnovano Planinarsko društvo), popraćene i muzejom planinarstva u Ogulinu (alpinistička zbirka u Zavičajnom muzeju Ogulin) i brojnim časopisima (Hrvatski planinar izlazi od 1898. godine), posljednjih se godina javlja novi trend koji planinarenje popularizira izvan i mimo planinarskih društava, Planinarskog saveza i časopisa Hrvatski planinar, kroz outdoor supkulturu i individualne priče koje od objava na društvenim mrežama (poput Facebooka, Instagrama itd.) ili na raznim portalima (npr. Outdoor.hr[, ${ }^{[1]}$ trcanje.hr, aktivan-zivot.hr, 3sporta.com, Index.hr) prerastaju u putopisno-meditativne publikacije, kroz trail ili multisport avanturističke utrke (poput ultra trail du Mont Blanc, ironmana ili u Hrvatskoj 100 milja Istre, Dalmacija ultra traila) i sl. Impuls koji je potaknuo ubrzani razvoj i popularizaciju aktivnosti na otvorenom nije došao s jednog mjesta, on je učinak artikulacije globalnih, ali i lokalnih ekonomskih i društvenokulturnih obrazaca koji su u posljednjih nekoliko desetljeća obilježeni velikim ubrzanjem života i porastom broja stanovnika u urbanim centrima, razvojem tehnologije i mrežnog društva, ali i učincima velikih globalnih kriza današnjeg vremena. Ekonomska kriza, ekološka kriza, migrantska kriza, zdravstvena kriza, da nabrojimo samo neke od kriza koje se međusobno isprepliću i prodiru u sve pore društva, manifestiraju se na različite načine: od rastuće prekarnosti, rasta broja dijagnostičkih kategorija depresije i anksioznosti, porasta ksenofobije, ali i ugroženosti kako kulturnih tako i prirodnih različitosti koje se manifestiraju nestankom određenih kulturoloških pogleda na svijet, ali i cijelih ekosustava. lako bi bilo zanimljivo analizirati isprepletenost svih tih „kriza” koje su između ostalog dovele do pojačanog naglašavanja čovjekove dobrobiti od boravka na otvorenom i doprinijele stvaranju atmosfere u kojoj prevladava osjećaj važnosti odlaska u prirodu, ovdje se više želimo posvetiti analizi percepcije planinskih krajolika koju posjetioci planina i prirode imaju. Kao što 
vidimo iz uvodnog citata Tomislava Birtića, ${ }^{[2]}$ čija je knjiga samo jedna u sve obilnijoj biblioteci planinarenja i outdoora u Hrvatskoj, o planinama se govori kao o mjestima koja vraćaju čovjeka njemu samome, ili prirodi, ili njegovu istinskom bitku. ${ }^{[3]}$ Postavlja se pitanje što znači taj „povratak prirodi”, koja su značenja utkana u njega, kako se on živi i osjeća? Inspirirane teorijama afekta, a posebno radovima teoretičarki Sare Ahmed i Lauren Berlant, odgovore na ta pitanja pokušavamo dati preko analize raznolikih priča posjetitelja planina u Hrvatskoj, koje zapravo funkcioniraju kao svojevrsni asamblaž ne samo doživljaja planine (ili prirode) već i same društvene atmosfere koja generira povratak prirodi kao nešto zdravo i/ili poželjno. Lauren Berlant društvenu atmosferu koja generira svakodnevicu konceptualno naziva povijesna sadašnjost. Za nju je povijesna sadašnjost uvijek afektivna, kao Williamsove „strukture osjećaja”,[4] i u stalnoj je promjeni, a ono što se trenutno događa često je predmet raznih debata o događanjima koja se smatraju uzročnicima trenutnog stanja (Berlant 4). U tom smislu ono što čini povijesnu sadašnjost uvijek je političko. S obzirom na to da živimo u trenutku koji je obilježen raznim krizama - od ekonomske, zdravstvene migrantske do ekološke - društvena atmosfera postaje zona konvergencije raznih povijesti gdje ljudi pokušavaju upravljati svojim životima i dalje rukovođeni određenim fantazijama o mogućnosti dobrog života, razvijajući razne vještine prilagodbe postojećem kriznom stanju. Za Berlant krizna stanja nisu iznimka, ona su ugrađena u život, u svakodnevicu koja se reflektira u „pričama o snalaženju u onome što je krizno" (8). Vještine prilagodbe generiraju se na razne načine, ovisno o socioekonomskim i drugim odrednicama (kao što su npr. dob, rod, etnicitet) i one se mogu odnositi na razne aspekte života. U ovom radu naš je fokus na vještinama prilagodbe koje se iskazuju kroz narative o planini i prirodi „kojoj se trebamo vratiti” i „doživjeti je” kako bi život postao „smisleniji ili zdraviji”. Važno je reći da se priroda od samih početaka razvoja konzumerističkog društva i pojave formalne distinkcije između radnog vremena i slobodnih aktivnosti komodificira na specifičan način, tako da osim za eksploataciju paralelno služi i kao identitarna odrednica za razne klase.[5] Korištenje prirode, a posebno planina u rekreacijske svrhe u početku je vezano za više klase, no s vremenom postaje i odrednica srednje klase iz urbanih centara, a i tu su postojale distinkcije koje su bile utemeljene u rodnim, etničkim i drugim kulturno-društvenim odrednicama. Ukratko, priroda postaje specifičan „objekt želje” kroz koji se prelamaju razni svjetonazori: od ideje „zdravog života”, „rekreacije”, „avanturizma”, „duhovne meditacije”, „osjećaja uzvišenog” do „potrebe zaštite”, 
„očuvanja”, „preživljavanja” itd. Po Ahmed objekti želje nas upućuju na analizu društvenih atmosfera koje omogućuju te svjetonazore, konzumiranje raznih identiteta i osjećaja pripadanja (The Promise of Happiness 21-49). Drugim riječima, omogućuju analizu regulativnosti društva kroz razne asocijacije vezane uz same objekte želje (na primjer rekreacioni aspekti ne asociraju na težak život seljaka u prirodi - na radnje kao što su skupljanje drveća za ogrjev, planinska ispaša stoke i sl.). U tom smislu možemo reći da „planina” kao i „priroda” funkcioniraju kao svojevrsni „ljepljivi znakovi” zasićeni afektom, kako bi rekla Ahmed, pri čemu ljepljivost omogućava prianjanje uz druge znakove (kao što su „zaštita prirodnih nacionalnih dobara”, „promoviranje zelenih politika” ili „promoviranje i komodificiranje ekoturizma”), što može u određenim situacijama uz znakove „uzvišenog” i „iskonskog” ili znakove „uzbudljivog” i „avanturističkog” dovesti do čitave lepeze novih značenja kao i cirkulacije različitih osjećaja (Kulturna politika emocija 129-33). Stoga je jedno od temeljnih pitanja koje se nameće u analizi percepcije i osjećaja koje izazivaju planine ili priroda općenito, a koji se iskazuju kroz razne naracije, na koje procese lijepljenja oni upućuju, na kojim fantazmama su utemeljeni te koje mogućnosti proizlaze iz njih.

\section{Fascinacija planinama}

Čovjekova fascinacija prirodom, a posebno planinama nije ništa novo, no s druge strane nije ni nešto što postoji oduvijek. Robert Macfarlane postulira da se tijekom posljednjih tristo godina dogodila ogromna promjena u percepciji Zapada glede planina. Predrasude prema planinama postojale su u Europi duboko u osamnaesto stoljeće. Na primjer, između 1580. i 1630., kada je u Europi bio jak progon „vještica”, pretpostavljalo se da su planine njihovo obitavalište, a oluje i mećave meteorološke manifestacije njihova orgijanja. Još početkom osamnaestog stoljeća gorska su područja smatrana zadnjim neukroćenim dijelovima prirode, divljina koja je čovjeku bila odbojna. Planine su smatrane greškom u inače skladnoj harmoniji krajolika sačinjenog od šuma, livada, oranica, voćnjaka, pašnjaka koje je čovjek mogao obrađivati i eksploatirati. Planine nisu bile ni agrikulturno ni estetski privlačne. Osim toga, bile su mjesta nepoznatog i opasnog, habitat nadnaravnog i neprijateljskog, bogova i čudovišta, krajolici koje je prosječan čovjek izbjegavao. Iznimka su bili oni koji su bježali i koristili planine kao zadnja utočišta u kojima se mogu sakriti od progona. Oni pak koji su prolazili blizu planinskih vrhova, poput hodočasnika, vojnika, trgovaca, 
nastojali su se što više držati podnožja planina, a vrhove su zaobilazili ni ne pomišljajući da se na njih popnu. Još duboko u 18. stoljeće putnici preko Alpskih prijevoja zakrivali su pogled od straha što će ugledati pri pogledu prema vrhovima planina.

Promjena se dogodila krajem 18. i u 19. stoljeću pod utjecajem razvoja geologije, romantizma i imperijalizma, kada se vrhove polako počinje štovati i oni zadobivaju sve značajnije mjesto u devetnaestostoljetnoj imaginaciji Europljana, smatra Macfarlane. Geološka istraživanja početkom 19. stoljeća stvaraju uvjete za novu generaciju „planinara”. Ona su geolozima dala razlog i opravdanje za odlazak u planine: proučavajući sedimente stijena i glečera, sakupljajući fosile, oni su stvarali novi pogled na Zemljinu povijest. Geolozi su prvi čitali krajobraz kao povijesne knjige i omogućili fascinaciju širih masa Zemljinim prošlim erama kao i geofizičkim silama. U to se vrijeme prvi put javlja i uzvisuje fascinacija strahom - ako se rizik u prethodnim razdobljima izbjegavao ili prihvaćao isključivo s nekom drugom svrhom poput znanstvenog napretka, slave ili financijske dobiti, kroz planinarstvo javlja se pomak u odnosu spram rizika i straha. Prema Macfarlaneu, smatralo se da rizik donosi nagradu i osjećaj ushita i uzbuđenja koje bismo danas pripisali učinku adrenalina. U tom trenu preuzimanje rizika i namjerno izazivanje straha postaju poželjni i počinju se komodificirati te se javljaju nove zajednice penjača, uglavnom pripadnika srednje klase koja se upravo kroz slobodne aktivnosti kao što je penjanje počinje samoidentificirati, uspostavljati kao različita u odnosu spram pripadnika nižih klasa (McNee 4-5). Takav je odnos spram straha odraz intelektualne doktrine uzvišenog, koja se razvija negdje sredinom 18. stoljeća, a koja je utjecala na promjenu u percepciji divljih krajolika i u odnosu spram straha. Uzvišeno kao doktrina oduševljava se kaosom, intenzitetom, kataklizmom, ekscesom, što je estetski antipod prethodnom razdoblju neoklasicizma. Godine 1757. u svom traktatu „Filozofsko istraživanje o nastanku naših ideja uzvišenog i lijepog” filozof Edmund Burke pisao je: „Što god pobuđuje ideju o boli i opasnosti, sve što je na bilo koji način strašno, grozno, zastrašujuće i sve što djeluje na način analogan teroru, izvor je uzvišenog, sublimnog, odnosno stvara najjače emocije koje um može osjetiti" (Burke u Macfarlane). Macfarlane zaključuje da je romantizam naštimao kolektivni živčani sustav 19. stoljeća da uživa u ekscesu i u vrijeme romantizma i romantičarske senzibilnosti strah postaje poželjan. Tako visine postaju privlačne sve većem broju ljudi. Krajem 18. i u prvim dekadama 19. stoljeća brojni pjesnici, slikari i pisci postaju senzibilni na vrhove i na sve ono što visina nosi: vjetar, 
svjetlo, zrak, a ponajviše od svega drugačiji pogled (vidi Mirzoeff 215). Visina omogućuje drugačija osjetilna iskustva. Krajobraz koji nam je možda i bio poznat iz uobičajene perspektive boravkom u nekom okolišu, dobiva sasvim drugačiji izgled pogledom s nekog vrha i za prve planinare to je bio sasvim novi doživljaj dotad nepoznat ljudskom iskustvu. Pogled s visine stvara u čovjeku osjećaj blaženstva koji nije kompetitivan, već kontemplativan, smatra Macfarlane (vidi Sallis 1-2).

Doživljaje prvih planinara tada možemo donekle usporediti s našim današnjim pogledom u svemir koji nam omogućuju fotografije koje su izradili teleskopi poput Hubblea, te satelitske ili dronske fotografije raznih krajobraza na Zemlji koje nam omogućuju sasvim novu perspektivu i kontekstualizaciju onoga što smatramo poznatim i već viđenim. Zato divljenje vrhovima i pogled s vrha planine postaje inspiracija i romantičarskim umjetnicima. Vrhovi postaju sinonim za osjećaj slobode i emancipacije duha, mjesta meditacije i prosvjetljenja - i od tada planine i vrhovi okupiraju ljudsku imaginaciju i pune se značenjima do mjere da im se pridaju osobine živog bića. I konačno, fascinacija vrhovima javlja se u vrijeme imperijalizma, kada znanost i ekonomija nastoje prodrijeti u svaki kutak Zemlje, upoznati i mapirati „najskrivenija” mjesta. Macfarlane postulira da je želja Britanaca da očiste globus od nepoznatih prostora odgovarala političkim ambicijama imperija, a francuski, britanski i ruski imperiji natjecali su se tko će osvojiti zadnja „neimenovana” i „nemapirana” područja planeta. Oni koji bi se vratili s takvih poduhvata dočekivani su kod kuće kao heroji i nacionalne zvijezde o kojima piše dnevni tisak. Da bi zaista dokazali gdje su bili, ostavljali su na „otkrivenim” područjima svoja imena, imperijske grafite kako to naziva Macfarlane.

Viktorijanski istraživači imenovali su nova mjesta kako bi krajolici koje su posjetili dobili značenje. Imenovanje, fiksiranje prisutnosti osobe ili događaja u vremenu i prostoru dopušta pričanje priča o tom krajobrazu, kao i besmrtnost onome tko ga je „otkrio”, često ignorirajući lokalna znanja o „otkrivenim” područjima. Za europske istraživače imenovanje daje značenje i strukturu prostoru koji bi inače bio beznačajan, ono oblikuje prostor i dopušta točkama u prostoru da budu u međusobnim odnosima. Imenovanje je način smještanja prostora unutar šire matrice značenja - način da se nepoznato učini poznatim, zaključuje Macfarlane. Dakle određeni sustavi znanja i svjetonazori kasnog 18. stoljeća doveli su do romantiziranja planina i planinskih vrhova, one postaju mjesta uzvišenih osjećaja, ali se zapravo percipiraju i kao mjesta na kojima je čovjek i fizički bliže bogu. Tako da bismo na neki način mogli zaključiti da i današnji odnos prema planinama ima tragove te romantičarske tradicije po kojoj je priroda inspirativna i pročišćavajuća, a planine mjesta uzvišenog, 
sublimnog, i strašnog istovremeno. Ta romantičarska percepcija planina cirkulira kroz noviju putopisnu literaturu, kao na primjer u Birtićevim knjigama gdje je osjećaj božanskog sadržan već i u samim naslovima: Šetnje s Bogom u gojzericama; Na Caminu sam zagrlio Boga itd. No važno je Birtićeve knjige kao i sličnu putopisnu literaturu koja naglašava mogućnost duhovnog prosvijetljena u prirodi smjestiti u globalni kontekst ekoloških, ekonomskih i društvenih okolnosti specifičnih za ovaj historijski trenutak, za povijesnu sadašnjost koja je primarno obilježena velikim krizama izazvanim neoliberalnim ekonomskim politikama i osjećajem nesigurnosti života, kao i ruiniranjem ustaljenih vrijednosnih sustava i vjere u ispravnost smjera kojim se svijet kreće.

\section{Povijesna sadašnjost i romantiziranje planina i prirode}

Povijesna sadašnjost za Berlant se, kao što smo već napomenule u uvodu, odnosi na atmosferu suvremenog trenutka. Možemo je promatrati kao Williamsove „strukture osjećaja”, kao „osjećaj kakvoće života na posebnom prostoru i vremenu", dojam o tome kako dolazi do nekog razmišljanja, dojam o „zajedništvu iskustva o kojem gotovo da i nije potrebno govoriti” (Williams 40). Za Berlant svaka povijesna sadašnjost manifestira se kao svojevrsni zastoj sustava (impasse) u kojem se mnogostruke temporalnosti usidre u određenom žanru. Pod žanrom ovdje se misli na klaster obećanja, područje emocija i osjetila koje nam pomažu spoznati organiziranost svakodnevice. Žanr organizira ljudske živote na način koji je prepoznatljiv drugima, izgleda razuman (žanr kao znanje koje je kolektivno prepoznato). Žanr je emocionalno oblikovan, strukturiran kao set očekivanja koja se odnose na to kako trebamo reagirati, djelovati ili interpretirati određene pojave. U tom smislu možemo reći da žanr organizira osjećaje, impresije kao i probleme povijesne sadašnjosti (Duschinsky i Willson 181). No postavlja se pitanje što se događa sa žanrovima u vrijeme krize, kada temeljni žanr postaje situacija koja remeti uobičajeno, stanje suspenzije uobičajenog, koje može a ne mora prerasti u novi žanr. Vrijeme u kojem živimo odlikuje se upravo takvim stanjem suspenzije, „zaglavljenosti u krizi”, impassom u kojem zastoj rastvara običan život, a uključuje i prilagodbu osjećaju krize. Za teoretičarke Annu Tsing i Donnu Haraway velike krize današnjice isprepliću se pod pojmom antropocen - erom najvećeg negativnog učinka čovjeka na planet koji nastanjuje. lako se geolozi ne mogu složiti oko toga kad je antropocen počeo, generalno se misli na period koji uključuje kolonizaciju i imperijalizam kao i 
industrijalizaciju. Donna Haraway govori i o plantažocenu kao razdoblju u kojem je plantažni uzgoj monokultura uništio biološku raznolikost i doveo do izumiranja brojnih životinjskih i biljnih vrsta diljem svijeta (Mittman), ali bitno utjecao i na normaliziranje odnosa moći u društvu (npr. patrijarhalnih odnosa i poimanja obitelji) kao i na ideju domestikacije prirode. Za Ghassana Hagea upravo u fantazmi mogućnosti domestikacije prirode leži ključ svih drugih kriza današnjice, uključujući ekološku, ekonomsku i migrantsku krizu - sve one proizlaze iz te fantazme. Domestikaciju Hage promatra kao generalni princip čovjekovog bivanja u svijetu, gdje se zapravo boljitak za čovjeka postavlja kao organizirajući princip (što bi značilo da se to odnosi kako na ukroćivanje prirode, osvajanje i eksploataciju prostora, tako i na ideju doma i svih svakodnevnih radnji koje obavljamo, a što podrazumijeva isključivanje ili eliminaciju svega onoga što se ne uklapa u fantaziju o poželjnom životu ili životu vrijednom življenja). U lakanovskoj psihoanalizi fantazma ili fantazija skup je uvjerenja pojedinaca i kolektiva zbog kojih osjećaju da njihov život ima svrhu, da imaju smislenu budućnost i održivost. Za Hagea fantazija u tom smislu pokriva važne elemente onoga što on naziva nadom, nadom u održiv život, uključuje čin identifikacije (pitanje subjekta) i usmjeravanje prema nečemu što se vidi kao „dobro”. No ova orijentacija, kako ističe Berlant kad govori o njoj kao o svojevrsnom žanru uključuje i tjeskobu, stvara nesigurnost koja je uvijek povezana s ranjivošću. Dakle, strukturno smo svi ranjivi, to jest svi živimo u svijetu utemeljenom na domestikaciji kao organizirajućem principu i na nas to utječe, to nas ometa, ometaju nas institucije za koje smo vezani, ljudi za koje smo vezani, a također i institucije i ljudi za koje nismo vezani, ali su nam važni, kako tvrdi Berlant. $U$ tom smislu naša je ranjivost uvijek povezana s političkom raspodjelom održivosti, s nečim što daje smisao našem životu kao životu vrijednom življenja. Kapitalistička aktivnost uvijek izaziva nesigurnost svojom opsežnom eksploatacijom ljudskih i neljudskih resursa. U tom procesu nesigurnost nikada nije bila ravnomjerno raspoređena niti se tako osjećala, ali ono što je specifično za suvremeni trenutak, kako ističe Berlant, jest da posljedice neoliberalnih kapitalističkih aktivnosti utječu na ljude više nego ikad prije. Sve to stvara nove uvjete života koji remete ustaljene fantazije o mogućnostima za „bolju budućnost”. Kao što Jameson tvrdi, „zbunjenost oko budućnosti kapitalizma postoji barem od kraja devetnaestog stoljeća, ali se malo razdoblja pokazalo nesposobnim kao što je to današnje razdoblje za stvaranje neposrednih alternativa za sebe" (704). Dakle novi životni uvjeti obilježeni velikim krizama i nesigurnošću, bez naznaka za rješenje problema u budućnosti, na različite 
načine obilježavaju društvene situacije i lokalitete i stvaraju kaotično afektivno okruženje koje karakterizira široko rasprostranjeno nepovjerenje u sustave i gdje se prilagođavanje krizi često čini uspjehom. Upravo u tom kontekstu „prilagođavanja krizi” javlja se i specifičan vid konzumerizma, koji se oslanja na krilaticu „budi svoj” (Salecl 8). Taj neoliberalni poticaj „budi svoj” postavlja sve životne odluke tako da se čine kao osobni izbori. Za Renatu Salecl to je ideologija kasnog kapitalizma koja funkcionira kao zataškavanje realne situacije u kojoj pojedinac zapravo nema mogućnost izbora, ne može utjecati na ekonomsku, zdravstvenu, migrantsku ili ekološku krizu, ali vjeruje da sam bira svoj životni stil ili orijentaciju kojom izražava određene stavove, tj. utječe na društvenu realnost. Na taj način, tvrdi Berlant (The Queen of America 1-20), razne individualne naracije o proživljenom iskustvu ili drugačijim i alternativnim načinima života ulaze u javnu sferu gdje se s jedne strane predstavljaju kao generičke, a s druge kao jako osobne, te na taj način javna sfera postaje intimna javna sfera u kojoj se politička pitanja prekrivaju osobnim iskustvima, osobnom etikom i moraliziranjem, razvijajući se time u područje kroz koje se adresiraju politička pitanja ili generalno pitanja koja se odnose na „život vrijedan življenja”. Smisao života popunjava se konzumiranjem raznih sadržaja, novim iskustvima od kojih su outdoor aktivnosti posebice postale popularne. Doživljaj poput odlaska u planine, ili bilo gdje u prirodu, predstavlja se kao zdrav život, uzbuđenje i avantura, odmak i bijeg od svakodnevnog stresa, izlaganje sebstva novim iskustvima i upoznavanje sebe na nove načine, pa raste broj onih koji se identificiraju kao planinari, penjači, avanturisti ili ekoturisti. Biti u prirodi, ili s prirodom, zadobiva novo značenje za određene grupacije ljudi, i to uglavnom pripadnike srednje klase, a doživljaj (u smislu emocije ili afekta) postaje ključna odrednica na kojoj se temelji smisao života. Za Berlant u suvremenom kontekstu u kojem je svakodnevica obilježena konstantnom krizom, emocija ili afekt zapravo postaju supstitut za djelovanje, tj. situacija u kojoj živimo zahtijeva rješenje, ali ono se stalno odgađa i ta obustava djelovanja (u smislu promjene stanja) osjeća se na različite načine: kao psihoza, anksioznost, stanje neizvjesnosti i bezizlaznosti, ali i zadovoljstvo; može poprimiti razne oblike i iz nje mogu proizaći razne naracije. $\mathrm{U}$ tom kontekstu promatramo i naracije koje romantiziraju prirodu, u kontekstu ideologije „budi svoj”, poput ove:

Koračanje prema Jezerima bilo je osjećaj povratka emociji, i vjeri u ljubav prirode. Ne vjeri u suživot čovjeka i prirode, na suživot pristaješ teška srca, nego dubokom osjećaju jedinstva, 
nedjeljivosti. Koža više nije ograda koja te dijeli od svemira. Hrana ima drukčiji okus. Treba ti sve manje soli. Vrijeme sve češće ne teče. (Birtić 152)

Zanimljivo je da Birtić naglašava kako svoje slobodno vrijeme provodi u prirodi koja mu je omogućila „povratak samom sebi” „onakvom kakav je bio prije nego što se rodio”. Stoga je boravak u prirodi itekako „koristan” i važan za svakog čovjeka. Njegova ideja o božanskom i nedjeljivosti čovjeka od prirode umrežena je paradoksalno s idejom „korisnosti za čovjeka” u „slobodno vrijeme” te iako u prvom trenutku izgleda kao da propituje dualizam čovjek/priroda (ili kultura/priroda), naglašavanjem iskonske povezanosti čovjeka s njegovim okolišem uspostavlja novi dualizam koji normalizira urbano kao zagađeno, a prirodno kao iscjeljujuće, stvarajući u „prirodnom” svojevrsni štit od užasa stvarnosti u urbanom, smještanje u neko zamišljeno iskonski sigurno mjesto. Birtićev narativ nije usamljen, uklapa se globalno gledano u narative o uzvišenosti prirode i ti narativi, iako lokalni, šire se zahvaljujući razvoju tehnologije i društvenim mrežama, preuzimajući status supkultura koje prevazilaze nacionalne granice. Oni ujedno funkcioniraju i kao nove identitarne odrednice, utemeljene na životnim orijentacijama koje uključuju pomak prema konzumiranju „Zdravog, iscjeljujućeg načina života”.

Međutim, važno je naglasiti da ovaj obrat prema prirodi kao uzvišenom, kao iscjeljenju, ne dijele svi korisnici prirode, pa tako jedan sugovornik smatra da je ideja o planinama kao iscjeljujućima „urbana priča” i zapravo je onima iz urbane sredine najlakše i „najjednostavnije otići u brdo i na čisti zrak" u trenutku kada se nagomilaju problemi izazvani urbanim načinom života. Isto tvrdi i sugovornica koja voli na romantičarski zanos o ljepoti života u prirodi komentirati: „Sad bi nas moja mama spustila na zemlju. Kad ja kažem - Joj kak je lijepo u Gorskom kotaru tam di si ti živjela na selu, ona veli - Odi pa živi, pa da vidiš kak je kad moraš po vodu hodati kilometrima, kilometrima nemaš dućana, kilometrima pješačiti kroz snijeg...” lako su danas i život na selu i život u prirodi lakši nego u vrijeme o kojem govori ovaj zadnji citat, nerijetko je ljudima iz urbanih sredina teško realizirati ono što su zamišljali životom u skladu s prirodom jednom kada dobiju priliku za to. No s druge strane i unatoč tome, postoji određeni trend odlaska mladih urbanih obitelji na život na selo, kao i trend samostalnog vrtnog uzgoja hrane za vlastite potrebe kao znaci povratka organskom, prirodnom, ekološkom ili nekom sličnom alternativnom stilu života koji je proizašao kao odgovor na „Život u krizi”. 


\section{Povijesna sadašnjost, outdoor industrija, avanturizam i nacionalni parkovi}

Još jedan od efekta suvremenih ekonomskih, ekoloških i političkih okolnosti, a odnosi se na doživljajnost prirode i afekte koji nastaju između čovjeka i prirode jest turistička i outdoor industrija kao i industrija tehnološke opreme koja prati outdoor aktivnosti: pametni satovi, mobiteli, aplikacije za praćenje aktivnosti, mjerenje fizioloških funkcija organizma, brojači kalorija, otkucaja srca, broja koraka, bilježenje GPS koordinata svakog pokreta, da spomenemo samo najbanalnije. Kada Katherine Hayles govori o postljudima (posthumanima) misli upravo na to, čovjeka duboko izmijenjenoga u interakciji s tehnologijom ${ }^{[6]}$ Pa je čovjek koji danas uživa u dobrobitima prirode, u svježem zraku fizičkoj aktivnosti nerijetko postao biće determinirano parametrima aplikacije kojom prati i dijeli s drugima svoju aktivnost u prirodi. Kao što kritički primjećuje i jedan od sugovornika, ljubitelj boravka na otvorenom i povremeni vodič višednevnih planinarskih tura po planinama i nacionalnim parkovima Hrvatske:

Sjećam se jednog statusa koji sam vidio na Facebooku o usponu na Triglav. Uz nekoliko slika sve što je pisalo uz status bilo je vrijeme (koliko je uspon trajao)... U cijelom tom statusu nije bilo ničega drugoga, dakle nije bila rečenica tipa: „Prekrasan sunčani dan”, ili: „Ptica, šum vjetra”, bilo što. Imam dojam da je sve češće fokus na toj nekoj mjerljivoj komponenti. Ja se trudim oduprijeti takvim izazovima i kad sam vani trudim se ne opterećivati se time.

Isti sugovornik naglašava kako je suvremena komodifikacija prirodnih lokaliteta od posebne važnosti, a nerijetko i zaštićenosti dovela do njihove ugroženosti. Napominjući kako u Hrvatskoj imamo slučajeve gdje se učinkovitost nacionalnih parkova mjeri brojem prodanih ulaznica, a ne radom na zaštiti flore i faune ili razvoju njene raznolikosti, zaključuje:

Dakle, mislim da je kod nas preveliki naglasak u parkovima dan na turizmu. Oni su postali skupljači novca i kad slušaš njihove nastupe u medijima oni gotovo isključivo govore o rezultatima (financijskim). Ne spominju ptice, biljke, gmazove, klimatske promjene, negativne utjecaje turizma

itd. ... Evo recimo jedan primjer. Na Krki se donedavno kao turistička atrakcija oglašavala mogućnost kupanja kod Skradinskog buka. Ti se na takvom mjestu ne bi smio kupati . . Imaš NP 
Krka, čiji je ključni dio Skradinski buk, i onda promoviraš to kao mjesto za kupanje. I onda dođu ljudi s ručnicima, ja te ljude i razumijem i ne razumijem, jer bili su pozvani kroz brošure na kupanje, ali kad dođeš tamo i vidiš o čem se radi, moraš biti budala da na onoj prašini raširiš ručnik i da tamo po onom skliskom kamenju među gomilom ljudi ulaziš i pokušavaš doći do onog slapa, a tamo zapravo i ne smiješ . . Sad ja razmišljam: zar osoba koja vodi nacionalni park misli da će stvarno izgubiti puno gostiju i toliko novca ukoliko se zabrani kupanje tamo? Kod Skradina je plaža, pa nek' se kupaju tamo, a ne kraj slapa da se uništava sedra. I sad nakon što ja tamo dolazim već 11 godina 4 - 5 puta godišnje, od prošle godine odjedanput više nema kupanja. Pa to je svaki normalan čovjek morao odavno shvatiti.

Idejno gledano nacionalni parkovi i parkovi prirode nastaju u 19. stoljeću kao odraz moderne i povezani su istovremeno s estetikom novog urbanog životnog stila koji tada nastaje, ali i s rizicima ekološke degradacije zbog raširene ekonomske eksploatacije (Campbell 282). Prvotne tendencije bile su svojevrsno getoiziranje prirode kako bi se ista zaštitila od ljudske intervencije. Kao rezultat ideja prirode se purificirala, što je dovelo do još jače podjele i učvršćivanja granica u oprečnosti priroda/kultura. Krajem 1960-ih godina zbog sve više kritičkih pogleda na takvu ideju zaštite prirode, a i s ekonomskim poslijeratnim razvojem, te nastankom ekoturizma, primarna ideja o zaštiti nacionalnih parkova počela se mijenjati. Oni sve više i više postaju turističke destinacije, a profit od turizma postaje značajan pokazatelj $u$ isplativosti financiranja nacionalnog parka ${ }^{[7]}$ lako se već od devedesetih prošlog stoljeća raspravlja o načinima na koje bi se olabavila oprečnost priroda/društvo u kontekstu nacionalnih parkova, u Hrvatskoj nacionalni parkovi još uvijek uglavnom funkcioniraju upravo na naglašavanju dihotomije priroda/kultura, nudeći konzumiranje „iskustva prirode”. Naglašavanje iskustva pokazuje i vezu između turizma i nacionalnih parkova, a ukazuje i na uključivanje osjeta, emocija kao i imaginacije. Stotine tisuća turista svake godine putuje svijetom, a većina in traži nezaboravna „iskustva”. Da bi ih privukli, svaka zemlja pokušava definirati svoju posebnost na sve kompliciranijem i zamršenijem svjetskom tržištu na kojem se natječu raznovrsna mjesta, kulture i krajolici za nova, drugačija, posebna iskustva. Ta posebnost natječe se s tisućama drugih u naizgled koherentnom svijetu suvremenog konzumerističkog užitka. Hrvatska svoju jedinstvenost i posebnost pokušava prikazati između ostalog kroz nacionalne parkove i parkove prirode. Stoga parkovi prirode i nacionalni parkovi kroz komodifikaciju igraju 
važnu ulogu, kako u turističkoj industriji tako i u nacionalnoj imaginaciji. Kao što je jedna zaposlenica parka prirode Telaščica navela u neformalnom razgovoru:

Većina posjetitelja, i onih iz Hrvatske kao i stranaca, odmah pita za aktivnosti koje nudimo. Interesira ih imamo li adrenalinski park, gdje se mogu kupati, traže da im osmislimo kako mogu provesti dan u prirodi... U početku budu razočarani kad shvate da većinu toga što su zamislili ne nudimo, ali na kraju se vrate s lijepim fotografijama, stavljaju selfije po društvenim mrežama... i u konačnici im bude ok. Na kraju krajeva provode vrijeme u jedinstvenoj prirodi kakvu ne mogu naći na drugim mjestima. Naši su ljudi posebno svjesni toga, te jedinstvenosti, na kraju krajeva svi trebamo biti ponosni na naše parkove.

I sam outdoor, koji je nastao među ljudima koji su ljubitelji aktivnosti na otvorenom, danas je velikim dijelom i svakim danom sve više komodificiran. Dok su prvi outdoor sportaši još ne tako davno bili planinari, alpinisti, turnoskijaši kojima je osnovni motiv bio boraviti u prirodi, a tek onda možda i vremenski rezultati, pojavom trail utrka ${ }^{8]}$ zadnjih 10 - 20 godina to se je znatno promijenilo[9] Istovremeno privučeni natjecateljstvom, u utrke ulazi sve više ljudi koji nisu bili primarno outdoor sportaši i koji imaju drugačije motive boravka na otvorenom, pa time i drugačiju etiku, gdje se ljubav prema aktivnostima na otvorenom i prema prirodi isprepliće sa željom za pobjedom, što dovodi do brojnih kompromitirajućih situacija u nekim okolnostima. Čak ni organizatori trail utrka u Hrvatskoj često nemaju svijest o nužnosti očuvanja područja na kojem se odvija utrka. Jedan sugovornik kritizira organizatore trail utrke koji su čitavu trasu utrke obilježili sprejajući kamenje na putu, iako je staza išla već markiranim, ucrtanim planinarskim putem zaštićenog parka prirode, pa nije bilo potrebe za takvom dodatnom devastacijom. O tome je pisao i na društvenim mrežama:

Eto, meni je neshvatjivo da Park prirode nije reagirao na tu moju objavu javno iako su tagirani. Dakle ne mogu reći da nisu vidjeli da je kamenje uz planinarsku stazu u zaštićenom području, Park prirode Velebit, nemilice išarano oznakama za trail utrku. Ja nisam neka osoba koja će njima napraviti neku štetu, ali trebali su se očitovati. Ali što će reći? Znam da oni već znaju za to jer je ta utrka počinjala na Baškim Oštarijama, gdje Park prirode ima svoju infokućicu, počinjala je kraj te njihove kućice. Ne mogu vjerovati da u godinu dana rendžeri parka nisu obišli taj kvart, da jesu morali su to vidjeti, ne mogu vjerovati da im je na bilo koji način to moglo promaći. 
Ovakav tip utrka sadrži u sebi i veliku dozu avanturizma, što je drugi komodificirani moment outdoor aktivnosti, a koji je osim trail utrka zahvatio u zadnje vrijeme i planinarenje. Koncept avanture zadnjih se godina pod pritiskom ekonomskih čimbenika značajno mijenja. Uz planinarska društva koja od svojeg postojanja ${ }^{[10]}$ svake godine održavaju planinarske škole u svrhu povećanja članova svojih društava i educiranja planinara koji će biti obučeni da mogu samostalno i sigurno boraviti u planinama, zadnjih godina sve je popularniji odlazak u planine osoba koje nisu stekle osnovna znanja o planinama, orijentaciji, opremi itd. Te osobe hodaju planinama u vodstvu licenciranih ili nelicenciranih i samoproglašenih vodiča, što je rezultiralo s nekoliko pojava. Prije svega, to je sam doživljaj avanture. Planinarima koji su obučeni za aktivnost kojom se žele baviti nikakva posebna avantura na Velebitu neće biti vidjeti poskoka ili medvjeda, budući da je to životni ambijent tih životinja, dok se ovim drugima upravo kroz takve zanimljivosti i izazove prodaju vođene ture. Prema riječima sugovornika, „medvjed je jedan od tih neizbježnih klišeja koji se pojavljuje u tekstovima o Velebitu, Gorskom kotaru itd... I sada, ako ti pišeš knjigu ili članak o Velebitu, bingo ti je ubaciti medvjeda... I onda ljudi to čitaju i onda počinje kolektivno asociranje Velebita s medvjedom, pa tako i kao izuzetno opasnog mjesta punog avanture". Nadalje, voditelji takvih izleta postaju mjerodavni i od javnosti prihvaćeni kao oni koji imaju znanje o tome što je prava avantura:

U vrlo kratkom vremenu dobili smo scenu u kojoj su najglasniji bili ti koji su dobili najviše pažnje medija i opet, kao i kod drugih stvari, ništa se nije propitivalo nego se stvari shvaćale zdravo za gotovo. Ljudi, pojedinci su dobivali na važnosti, a da nikakvog uvida u stvarnu „vrijednost” putovanja mi nismo dobili. Kad kažem vrijednost mislim na ono što oni sami apostrofiraju kao vrijednost - izazov, avanturu, nepoznato itd., a što je u praksi daleko od toga.

Druga je pojava, kao što najavljuje gornji citat, da u skladu s takvim prikazivanjem banalnih putovanja kao avanturističkih i isticanjem voditelja takvih putovanja kao mjerodavnih arbitra avanture nastaje sve učestalija putopisna literatura koja nastavlja s takvim „prodavanjem priče”, kako to naziva jedan od naših sugovornika:

U našoj putopisnoj literaturi mislim da prevladava fascinacija neobičnim, egzotičnim, dramatičnim. Ta fascinacija neobičnim dovela je do toga da ljudi koriste riječi avantura, prvi, jedini, teško, 
opasno... vrlo olako. To je ono što se meni čini nepotrebnim i što stavlja putopisnu literaturu tamo kamo je naše ministarstvo i smješta, dakle u nekakvu nekvalitetnu zabavnu kategoriju, a ne u književni žanr koji su stvarali i održavali veliki pisci poput Therouxa, Thesigera, Chatwina, Steinbecka, Naipula, da navedem samo par. Dakle veliki pisci pisali su putopise, neki su bili $i$ nobelovci...

Ova pojava opet nije karakteristična samo za Hrvatsku. Globalno gledano ono što se naziva planinarskim ili treking putovanjima u visoke gore svijeta, kroz priču o jedinstvenoj životnoj avanturi prodaje se mladima, uglavnom visokog financijskog statusa, kao ultimativna ekspedicija. Vrhunac apsurdnosti te pojave jest to što se danas na najvišu planinu svijeta Mt. Everest uspinju ljudi koji ne znaju ni osnove alpinizma, a nakon takvog vođenog uspona u kojem vodiči i sherpe odrade sav tehnički dio vezan uz uspon bivaju priznati kao vrhunski alpinisti! ${ }^{[11]}$

I na kraju, za neke avanturizam znači pokazivanje tehnološke nadmoći nad prirodom. Sve popularnije probijanje neprohodnim planinskim stazama enduro motorima ili quadovima do vrhova planina određenom broju ljudi predstavlja ultimativnu avanturu, a kao takvo nudi se i u brošurama i katalozima brojnih turističkih agencija.

\section{Zaključak}

U zaključku bismo se vratile na pitanja koja smo otvorile u uvodu ovog rada, a koja se odnose na različite percepcije planine i prirode u suvremenom kontekstu, prostoro-vremenu obilježenom raznim globalnim krizama (ekonomskom, migrantskom, klimatskom, zdravstvenom) i nesigurnošću odnosno nestabilnošću života (prekarnošću). Za Berlant nesigurnost života nikad nije samo individualna, ona je uvijek zapetljana s političkom distribucijom pojma „održivosti” (života vrijednog življenja) koji generira različite odnose, ljudske i neljudske. Neoliberalna kapitalistička ekonomska praksa, koja je i temeljni generator današnjih kriza, između ostalog potiče ideju održivosti (života vrijednog življenja) promovirajući fantazmu „poboljšanja samog sebe” kako bi se što bolje nosili s krizama u kojim živimo, radili što učinkovitije, živjeli što zdravije i dobro koristili svoje slobodno vrijeme. $U$ tom kontekstu došlo je i do učestalijeg i masovnijeg boravka na otvorenom, a pogotovo u prirodi, kao zdravog antistresnog načina života. U našem istraživanju s različitim korisnicima planine i prirode zanimalo nas je kako ljudi vide taj suvremeni pojačani interes za prirodu, koja joj 
značenja u svojim naracijama pridaju. I kako je naše istraživanje pokazalo, „planine” kao i „priroda” mogu imati različita značenja i mogu se doživjeti na mnogo različitih načina: od sublimnih mjesta koja donose duhovno prosvijetljene i osjećaj harmonije, planine kao mjesta utrke i usavršavanja tijela, planine kao pustolovine u kojoj se traži iskustvo „otkrića” i „straha od nepredvidljivog i nepoznatog", planine i prirode kao mjesta opuštanja i razonode ili bijega od svakodnevice, do planine i prirode koju treba štititi u smislu bioraznolikosti. Svi ti razni vidovi iskustva bivanja u prirodi svojevrsna su obrana od nesigurnosti života (i ranjivosti koja uz to ide), pokušaji da se pronađe održiv život, „život vrijedan življenja”, a ujedno predstavljaju i identitarne odrednice, razne oblike subjektiviteta koji su dio globalnog konzumerizma. U tom smislu možemo reći da „priroda” postaje ljepljiva riječ, dio globalne afektivne ekonomije koja omogućuje ljepljivu povezanost „među znakovima, likovima i objektima”, a ono što se lijepi povezano je s „odsutnom prisutnošću povijesnosti” (Kulturna politika emocija). Priroda istovremeno postaje „objekt sreće” (zdravi život, sublimnost, avanturizam, uzbuđenje), ali i „objekt nelagode” (devastacija prirodnih resursa, globalne klimatske promjene). Ona ujedno obećava sreću bez obzira na surovost sustava u kojem živimo (i koji se manifestira kroz razne krize), ali je i podsjetnik „nesigurnosti života”, koji se odnosi na neoliberalnu kapitalističku ekonomsku praksu koja kroz desetljeća „nabire” političku, ekološku i društvenu „krhkost”, koja potom na različite načine preoblikuje ideje o „Životu vrijednom življenja”.

\section{Bibliografija}

Ahmed, Sara. Kulturna politika emocija. Fraktura, 2020.

Ahmed, Sara. The Promise of Happiness. Duke University Press, 2010.

Berlant, Lauren. The Queen of America Goes to Washington City: Essays on Sex and Citizenship. Duke University Press, 1997.

Berlant, Lauren. Cruel Optimism. Duke University Press, 2011.

Birtić, Tomislav. Šetnje s Bogom u gojzericama. Rafineranija ideja, 2016.

Birtić, Tomislav. Na Caminu sam zagrlio Boga. Rafineranija ideja, 2019.

Campbell, Ben. „Changing Protection Policies and Ethnographies of Environmental Engagement”. Conservation and Society, vol. 3, br. 2, 2005, str. 280-322. 
Duda, Dean, urednik. Politika teorije: zbornik rasprava iz kulturalnih studija. Disput, 2006.

Duschinsky, Robbie i Emma Willson. „Flat Affect, Joyful Politics and Enthralled Attachments:

Engaging with the Work of Lauren Berlant”. International Journal of Politics, Culture and Society, vol. 28, 2015, str. 179-90.

Hage, Ghassan. Is Racism an Enviromental Threat? Polity, 2017.

Haraway, Donna. J. Simians, Cyborgs and Women: The Reinvention of Nature. Routledge, 1991.

Haraway, Donna. Staying with the Trouble. Duke University Press, 2016.

Hayles, Katherine N. How We Became Posthuman: Virtual Bodies in Cybernetics, Literature, and Informatics. The University of Chicago Press, 1999.

Macfarlane, Robert. Mountains of the Mind: a History of a Fascination. Vintage, 2004.

McNee, Alan. „The Haptic Sublime and 'the cold stony reality' of Mountaineering“. The Victorian Tactile Imagination, vol. 19, 2014. Interdisciplinary Studies in the Long Nineteenth Century, 19.bbk.ac.uk/article/id/1673/. Pristupljeno 17. rujna 2021.

Mirzoeff, Nicholas. How to See the World. Basic Books, 2016.

Mittman, Gregg. Reflections on the Plantationocene: A Conversation with Donna Haraway and Anna Tsing, podcast. 2019. edgeeffects.net/haraway-tsing-plantationocene/. Pristupljeno 22. siječnja 2021.

Outdoor.hr. www.outdoor.hr/index.php. Pristupljeno 15. studenog 2021.

Salecl, Renata. Tiranija izbora. Fraktura, 2012.

Sallis, John. Topographies. Indiana Universtiy Press, 2006.

Smith, Neil. Uneven Development: Nature, Capital, and the Production of Space. Basil Blackwell, 1984.

Tsing, Anna. The Mushroom at the End of the World. Princeton University Press, 2015.

UTMB MONT-BLANC. 2021, utmbmontblanc.com/cn/page/20/utmb.html. Pristupljeno 8. siječnja 2021. 
Williams, Raymond. „Analiza kulture.” Politika teorije: zbornik rasprava iz kulturalnih studija, uredio Dean Duda, Disput, 2006, str. 35-58. 
[1] „Outdoor.hr programi utjelovljuju 15 godina praktičnog iskustava u organizaciji aktivnog odmora, pustolovnih putovanja, team building programa, korporativnog treninga, kongresa, seminara i mnogobrojnih sportskih, turističkih i zabavnih manifestacija i događanja kao što su Treking liga, Urban Challenge i Terra Incognita" (Outdoor.hr).

[2] Brojni naši sugovornici na terenu na isti način kao Birtić gledaju na odlazak u prirodu ili planine, pa možemo reći da je spomenuti citat reprezentativan na široj razini od individualne. Istraživanje o percepciji prirode provodile smo u periodu od 8 mjeseci (od siječnja do kolovoza 2021. godine). U tom periodu vodile smo 18 neformalnih intervjua s različitim outdoor entuzijastima, od profesionalnih planinara, turista kao i vodiča po parkovima prirode i nacionalnim parkovima. Svi intervjui provedeni su u „prirodi”, na raznim lokacijama, kao i u planinarskim domovima.

[3] Uz spomenutog Birtića postoji čitav niz takvih knjiga. Navodimo ovdje još: Šavorić, Tatjana. Moja planina - Kroz gore uz more, od Prevlake do Istre. VBZ, 2021.; Majerović-Stilinović, Milan. Što sam naučio na planini. Libricon, 2020.; Popović, Edo i Ante Vukušić. Čovjek i planina. Libricon, 2018.; Rac, Krunoslav. Velebit: iskustvo planine. Profil multimedija, 2010.

[4] Vidi: Willimas, Raymond. „Analiza kulture.” Politika teorije: zbornik rasprava iz kulturalnih studija, uredio Dean Duda, Disput, 2006, str. 35-58.

[5] O pitanju klase i konzumiranja prirode postoje mnogi radovi, a ovdje upućujemo na: Khan, Farieda. „The Century of Mountaineering - Race, Class, and the Politics of Climbing“. Acta Academica, vol. 50, br. 2, 2018, str. 52-74.; Bajič, Blaž. „Meni je ta moja pot kot dnevna soba: tekači v Ljubljani in njihove poti kot povezava med mestom in naravo“. Etnolog, vol. 26, 2016, str. 165-86.

[6] I Donna Haraway u svojoj knjizi Simians, Cyborgs and Women. The Reinvention of Nature govori o ambivalentnosti granice između čovjeka i strojeva.

[7] Neil Smith (Uneven Development: Nature, Capital, and the Production of Space) - razvija teoriju produkcije prirode i objašnjava kako su i nacionalni parkovi proizvedena okruženja u svakom smislu: od praćenja i upravljanja kretanja divljih životinja do promjene krajobraza; od restorana i kampova do razglednica - sve su to upakirana kulturna iskustva okoliša proizvedena 
kako bi stvorila profit. Kapitalistički način proizvodnje proizvodi prirodu kao prostor onkraj društva i kao takvog ga koristi.

[8] Outdoor sportovi jesu svi sportovi koji se odvijaju na otvorenom, a trail utrke su utrke koje se odvijaju planinarskim stazama i/ili planinskim krajolicima. One se razlikuju od avanturističkih utrka koje se također odvijaju na otvorenom, ali ne nužno u planinama.

[9] Najveća i najprestižnija europska trail utrka Ultra trail du Mont Blanc, koja podrazumijeva 171 km trčanja planinarskim stazama i 10000 visinskih metara, a traje između 20 i 46 sati, ovisno o spremnosti trkača, prvi je put održana 2003. godine. Od tada do danas na takve se utrke prijavljuje enormni broj trkača iz čitavog svijeta, zbog čega su organizatori morali uvesti razne oblike kvalifikacija kako bi broj trkača sveli na količinu kojom će biti moguće logistički upravljati. Prosječno u utrci sudjeluje 2300 trkača, kotizacija za utrku je 280 eura, a nagrade za prva i prve tri plasirane iznose 2000, 1500 i 1000 eura (UTMB MONT-BLANC).

[10] U Zagrebu postoje brojna planinarska društva, no ona najstarija su PD Zagreb Matica osnovana 1948. te PD Željezničar i PDS Velebit osnovani 1950. godine.

[11] Ovdje se javlja i asocijacija s europskom kolonijalnom idejom osvajanja vrhova planina krajem devetnaestog i početkom dvadesetog stoljeća, kada su se u potpunosti ignorirali lokalno znanje i lokalni ljudi koji su kao radnici sudjelovali u ekspedicijama.

\section{(c) (i) $\ominus$}

Creative Commons Attribution-NonCommercial-NoDerivatives 4.0 International License 